\title{
Malcolm Ferguson-Smith
}

Quite often some of the most innovative and productive scientists are those with extremely varied backgrounds. Malcolm Ferguson-Smith, the first scientist to be honored in this series, is such a person. Purely on the basis of his publications few would realise that Malcolm has been a pathologist all his working life. It was his early interest in the pathology of human sexual development and the possible role of the Barr body which first led him into human cytogenetic studies in the late 1950s. That interest in sex determination has continued for nearly 50 years up to the present day, as we see from his last listed publication on the complex X-Y chromosome constitution of the duck-billed platypus. The difference between visualizing the humble Barr body and the breath-taking magnificence of the multi-chromosome and multi-fluor images of the platypus sex chromosomes is indeed a life-time apart and Malcolm Ferguson-Smith has been central in those developments. It was he who first recognised the potential of flow cytometry for isolating individual chromosomes to address the clinical problems of particular patients. At that time, during the mid-1980s, the conventional wisdom was that chromosomes could only be efficiently sorted using the especially developed and super-expensive high-speed sorters at the Los Alamos and Lawrence Livermore laboratories in the USA. However, several groups in Europe, including that of Malcolm, Brian Young and others, demonstrated that commercially available cell sorters could also be successfully used, if somewhat more slowly, for the same purpose. In parallel to the sorting, FISH methods were being developed by others, but notably the introduction of PCR protocols which could be used for amplifying DNA from sorted chromosomes was a break-through (Telenius et al., 1992) and essential to developing chromosome-specific paints from sorted chromosomes on a large scale. Malcolm and his group went on to use sorted chromosomes in reverse painting, i.e. hybridizing DNA from sorted aberrant human chromosomes back onto normal metaphases to demonstrate the origin of the aberration (Carter et al., 1992). Malcolm's group proceeded to sort the chromosomes of other species to produce chromosomespecific paints with the mouse being the most notable (Liyanage et al., 1996). Undoubtedly, one of the most extraordinary developments was the discovery that chromosome-specific

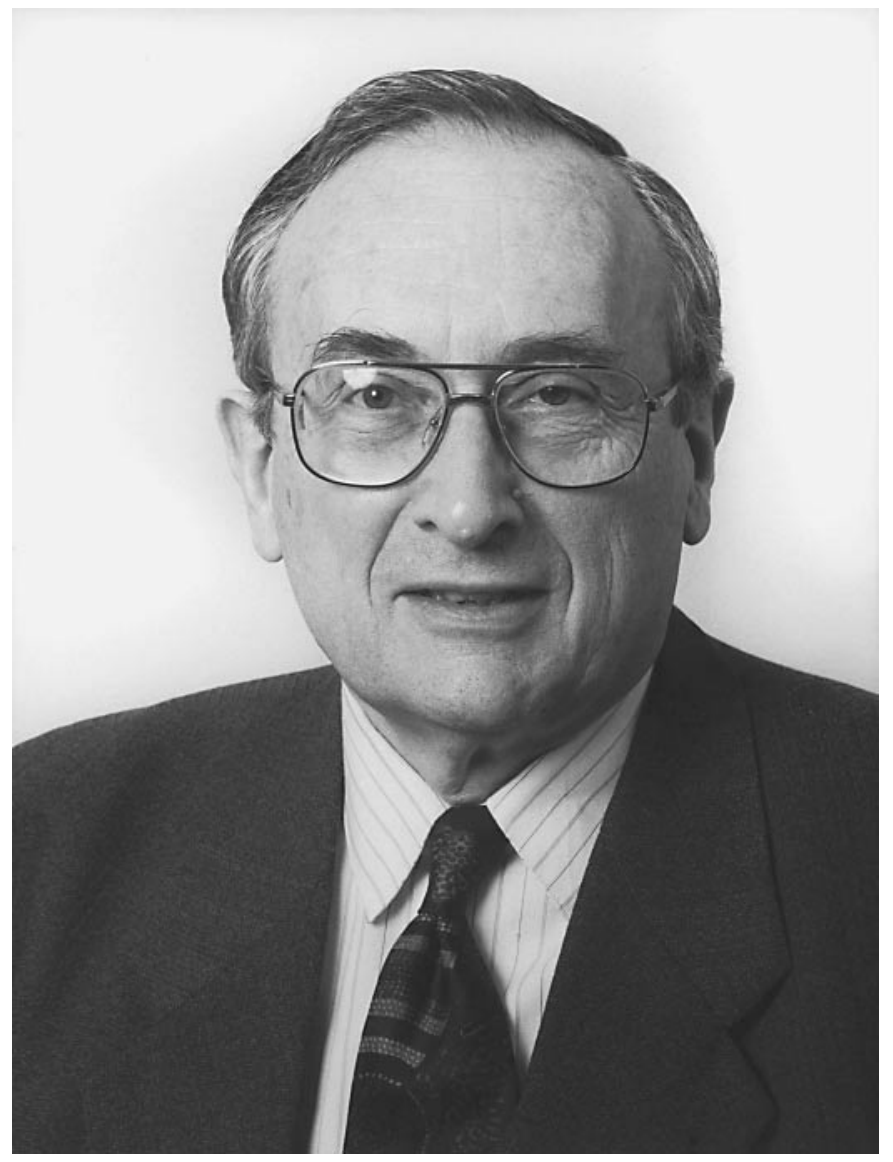

paints of one species could be successfully hybridized to the chromosomes of another to demonstrate homology (Mueller et al., 1998; Yang et al., 1999; Yang et al., 2000) facilitating widescale evolutionary studies in vertebrates. For the true aficionados of meiosis three articles (Ferguson-Smith and Page, 1973; Winsor et al., 1978; Brown et al., 1998) are gems and deal with 
aspects that have both fascinated and frustrated human cytogeneticists for decades. Perhaps Malcolm's most sanguine contribution and for which he will be rightly remembered for the longest is his 1966 letter to the Lancet (Ferguson-Smith, 1966a) in which he proposed that the XX male phenotype derives from an unequal meiotic exchange between the $\mathrm{X}$ and the $\mathrm{Y}$ chromosome resulting in transfer of the male-determining factor from the $\mathrm{Y}$ to the $\mathrm{X}$. This was at a time when it was not even known which arms of the $\mathrm{X}$ and $\mathrm{Y}$ paired with each other or the extent of the pairing segment and predated the use of XX males with differing levels of $\mathrm{XY}$ interchange to dissect and map the $\mathrm{Y}$ chromosome by some 20 years. Amongst his many career activities Malcolm has been a member of the editorial board and regular contributing author of this journal.

On behalf of the Editorial Board Peter Pearson

\section{Curriculum vitae}

Malcolm Ferguson-Smith is currently Research Professor in the Department of Veterinary Medicine, University of Cambridge, UK. He was born in Glasgow in 1931, graduated in medicine at Glasgow University in 1955 and, while undertaking postgraduate training there in pathology, was introduced to research on sex chromatin under Bernard Lennox. Their buccal smear surveys revealed for the first time the high frequency of Klinefelter's syndrome among subfertile males and among those with learning difficulties. Unsuccessful efforts to undertake chromosome analysis in these patients in 1957-58 led to an appointment as Fellow in Medicine at John's Hopkins in 1959 and he remained there working on chromosomes for nearly three years. During this time he established the first chromosome diagnostic service in the USA and undertook cytogenetic research into the Turner syndrome and true hermaphroditism. Returning to Glasgow University in late 1961, he was appointed successively, Lecturer, Senior Lecturer and Reader before becoming Professor of Medical Genetics in 1973. His duties included teaching genetics to first and fourth year medical students and the establishment of a Regional Genetic Service for the West of Scotland comprising counselling clinics, diagnostic laboratories, prenatal diagnosis and screening. The clinical cytogenetics service provided opportunities for contributing to the human gene map using familial chromosome polymorphisms, deletion mapping, in situ hybridisation and chromosome sorting by flow cytometry. In all these aspects of diagnosis and research he was ably supported by his wife, Marie, and an exceptional team of post-docs and technicians. Grant support was provided by the MRC, the Scottish Home \& Health Department, the Scottish Hospitals Endowment Trust and the Medical Charities. An initiative by Action Research for the Crippled Child led to the building of the Duncan Guthrie Institute of Medical Genetics in Glasgow in 1980. In 1987 he was appointed Head of Pathology at Cambridge University and Director of the East Anglia Regional Genetics Service. Research continued on gene isolation, fluorescence in situ hybridisation, reverse chromosome painting and studies in karyotype evolution using cross-species chromosome painting. On retir- ing from the headship of Pathology in 1998, Professor Ferguson-Smith and his small team moved to labs in the Cambridge University Centre for Veterinary Science, to establish the Cambridge Resource Centre for Comparative Genomics supported by the Wellcome Trust. During his long and happy career in medical genetics he has had a number of honorary administrative duties including Vice-President of the Genetical Society and President of the Clinical Genetics Society, President of the European Society of Human Genetics, President of the International Society for Prenatal Diagnosis and is currently President of the Association of Clinical Cytogeneticists. He was elected Fellow of the Royal Society of Edinburgh in 1978, the Royal Society of London in 1983, the Royal College of Obstetricians \& Gynaecologists in 1993 and the Academy of Medical Sciences in 1998. He is a Foreign Member of the Polish Academy of Science and of the National Academy of Medicine of Buenos Aires and is an Honorary Associate of the Royal College of Veterinary Surgeons. He has Honorary Doctorates in Science from the Universities of Glasgow and Strathclyde. His editorial duties have included membership of the Board of Cytogenetics from 1961 to 1971 and of its successor from 1972 to 1982; in 1980 he became the founding editor of Prenatal Diagnosis. With J.M. Connor his undergraduate textbook "Essential Medical Genetics" has run to five editions.

\section{0 selected publications in chronological order, 1957-2004}

Ferguson-Smith MA, Lennox B, Mack WS, Stewart JSS: Klinefelter's syndrome: frequency and testicular morphology in relation to nuclear sex. Lancet II:167-169 (1957)

Ferguson-Smith MA, Johnston AW, Handmaker SD: Primary amentia and micro-orchidism associated with an XXXY sex chromosome constitution. Lancet II:184-187 (1960).

Ferguson-Smith MA, Handmaker SD: Observations on the satellited human chromosomes. Lancet I:638-640 (1961).

Ferguson-Smith MA, Ferguson-Smith ME, Ellis PM, Dickson M: The sites and relative frequencies of secondary constrictions in human somatic chromosomes. Cytogenetics 1:325-343 (1962).

Ferguson-Smith MA: The sites of nucleolus formation in human pachytene chromosomes. Cytogenetics 3:124-134 (1964).

Ferguson-Smith MA, Mack WS, Ellis PM, Dickson M, Sanger R, Race RR: Parental age and the source of the X chromosomes in XXY Klinefelter's syndrome. Lancet I:46 (1964).

Ferguson-Smith MA: Karyotype-phenotype correlations in gonadal dysgenesis and their bearing on the pathogenesis of malformations. J Med Genet 2:142-155 (1965)

Ferguson-Smith MA: Sex chromatin, Klinefelter's syndrome and mental deficiency, in Moore KL (ed): The Sex Chromatin, pp 277-315 (W.B. Saunders, Philadelphia 1966a).

Ferguson-Smith MA: X-Y chromosomal interchange in the aetiology of true hermaphroditism and of XX Klinefelter's syndrome. Lancet II:475-476 (1966b).

Ferguson-Smith ME, Ferguson-Smith MA, Nevin NC, Stone M: Chromosome analysis before birth and its value in genetic counselling. Brit Med J 4:69-74 (1971)

Allan LD, Ferguson-Smith MA, Donald I, Sweet E, Gibson AAM: Amniotic fluid alphafetoprotein in the antenatal diagnosis of spina bifida. Lancet II:522-525 (1973).

Ferguson-Smith MA: Inherited construction fragility of chromosome 2. Ann Genet 16:29-34 (1973).

Ferguson-Smith MA, Page BM: Pachtyene analysis in a human reciprocal (10;11) translocation. J Med Genet 10:282-287 (1973). 
Ferguson-Smith MA, Newman BF, Ellis PM, Thomson DMG, Riley ID: Assignment by deletion of human red cell acid phosphatase gene locus to the short arm of chromosome 2. Nature New Biol 243:271-274 (1973).

Ferguson-Smith MA, Aitken DA, Turleau C, de Grouchy J: Localisation of the human ABO:Np-1:AK-1 linkage group by regional assignment of AK-1 to 9q34. Hum Genet 34:35-43 (1976).

Ferguson-Smith MA, Rawlinson HA, May HM, Tait HA, Vince JD, Gibson AAM, Robinson HP, Ratcliffe JG: Avoidance of anencephalic and spina bifida births by maternal serum alphafetoprotein screening. Lancet I:1330-1333 (1978).

-Winsor EJT, Palmer CG, Ellis PM, Hunter JLP, Ferguson-Smith MA: Meiotic analysis of a pericentric inversion, inv(7)(p22q32), in the father of a child with a duplication-deletion of chromosome 7. Cytogenet Cell Genet 20:169-184 (1978)

- Malcolm S, Barton P, Murphy CST, Ferguson-Smith MA: Chromosomal localisation of a single copy gene by in situ hybridisation: human Bglobin genes on the short arm of chromosome 11. Ann Hum Genet 45:135-141 (1981)

Young BD, Ferguson-Smith MA, Sillar R, Boyd E: High resolution analysi of human peripheral lymphocyte chromosomes by flow cytometry. Proc Natl Acad Sci USA 78:7727-7731 (1981).

Ferguson-Smith MA, Sanger R, Tippett P, Aitken DA, Boyd E: A familial $\mathrm{t}(\mathrm{X} ; \mathrm{Y})$ translocation which assigns the $\mathrm{Xg}$ blood group locus to the region Xp23-pter. Cytogenet Cell Genet 32:273-274 (1982).

- Malcolm S, Barton P, Murphy C, Ferguson-Smith MA, Bentley DL, Rabbitts $\mathrm{TH}$ : Localisation of human immunoglobin $\kappa$-light chain variable region genes to the short arm of chromosome 2 by in situ hybridisation. Proc Natl Acad Sci USA 79:4957-4961 (1982).

Ferguson-Smith MA, Yates JRW: Maternal age specific rates for chromosome aberrations and factors influencing them. Report of a Collaborative European Study on 52965 amniocenteses. Prenat Diagn 4:5-44 (1984).

Affara NA, Ferguson-Smith MA, Tolmie J, Kwok K, Mitchell M, Jamieson D, Cooke A, Florentin L: Variable transfer of Y-specific sequences in XX males. Nucleic Acids Res 14:5375-5387 (1986).

-Simpson E, Chandler P, Goulmy E, Disteche DM, Ferguson-Smith MA, Page DC: Separation of the genetic loci for the H-Y antigen and for testis determination on human Y chromosome. Nature 326:876-878 (1987).

-Yates JRW, Ferguson-Smith MA, Shenkin A, Guzman-Rodriguez R, White M, Clark BJ: Is disordered folate metabolism the basis for the genetic predisposition to neural tube defects? Clin Genet 31: 279-287 (1987).

- Carter NP, Ferguson-Smith MA, Perryman MT, Telenius H, Pelmear AH Leversha MA, Glancy MT, Wood SL, Cook K, Dyson HM, FergusonSmith ME, Willatt LR: Reverse chromosome painting: a method for the rapid analysis of aberrant chromosomes in clinical cytogenetics. $\mathrm{J}$ Med Genet 29:299-307 (1992).

- Telenius H, Pelmear AH, Tunnacliffe A, Carter NP, Behmel A, FergusonSmith MA, Nordenskjold M, Peragner R, Ponder BAJ: Cytogenetic analysis by chromosome painting using DOP-PCR amplified flow-sorted chromosomes. Genes Chromosomes Cancer 4:257-263 (1992).

-Goudie DR, Yuille MAR, Leversha MA, Furlong RA, Carter NP, Lush MJ, Affara NA, Ferguson-Smith MA: Multiple self-healing squamous epithelioma (ESSI) mapped to 9q22-q31 in families with common ancestry. Nat Genet 3:165-169 (1993).

-McVey JH, Michaelides K, Hansen LP, Ferguson-Smith MA, Tilghman S, Krumlauf R, Tuddenham EGD: A G-A substitution in an HNFI binding site in the human $\alpha$-fetoprotein gene is associated with hereditary persistence of $\alpha$-fetoprotein (HPAFP). Hum Mol Genet 2:379-384 (1993)

-Sargent CA, Affara NA, Bentley E, Pelmear A, Bailey DMD, Davey P, Dow D, Leversha M, Aplin H, Besley GTN, Ferguson-Smith MA: Cloning of the X-linked glycerol kinase deficiency gene and its identification by sequence to the Bacillus subtilis homologue. Hum Mol Genet 2:97-106 (1993).

Zheng Y, Carter NP, Price CM, Coleman SM, Milton PJ, Hackett GA, Greaves MF, Ferguson-Smith MA: Prenatal diagnosis from maternal blood: simultaneous immunophenotyping and FISH of fetal nucleated erythrocytes isolated by negative magnetic cell sorting. J Med Genet 30:1051-1056 (1993)

Divane A, Carter NP, Spathas DH, Ferguson-Smith MA: Rapid prenatal diagnosis of aneuploidy from uncultured amniotic fluid cells using fivecolour fluorescence in situ hybridisation. Prenat Diagn 14:1061-1069 (1994).
Rabbitts P, Impey H, Heppel-Parton A, Langford C, Tease C, Lowe N, Bailey D, Ferguson-Smith MA, Carter N: Chromosome specific paints from a high resolution flow karyotype of the mouse. Nat Genet 9:369-375 (1995).

Yang F, Carter NP, Shi L, Ferguson-Smith MA: A comparative study of karyotypes of muntjacs by chromosome painting. Chromosoma 103:642-652 (1995).

Liyanage M, Coleman A, du Manoir S, Veldman T, McCormack S, Dickson RB, Barlow C, Wynshaw-Boris A, Janz S, Wienberg J, Ferguson-Smith MA, Schröck E, Ried T: Multicolour spectral karyotyping of mouse chromosomes. Nat Genet 14:312-315 (1996).

Schrock E, du Manoir S, Veldman T, Schoell B, Wienberg J, Ferguson-Smith MA, Ning Y, Ledbetter D, Bar-Am I, Soenksen D, Garini Y, Ried T: Multicolor spectral karyotyping of human chromosomes. Science 273:494-497 (1996).

Ferguson-Smith MA: Genetic analysis by chromosome sorting and painting: phylogenetic and diagnostic applications. Eur J Hum Genet 5:253-265 (1997).

Brown GM, Leversha M, Hulten M, Ferguson-Smith MA, Affara NA, Furlong RA: Genetic analysis of meiotic recombination in humans by use of sperm typing: reduced recombination within a heterozygous paracentric inversion of chromosome 9q32-q34.3. Am J Hum Genet 62:1484-1492 (1998).

-Mueller S, O'Brien PCM, Ferguson-Smith MA, Wienberg J: Cross species colour segmenting: a novel tool in human karyotype analysis. Cytometry 33:445-452 (1998).

- Griffin DK, Haberman F, Masabanda J, O’Brien PCM, Bagga M, Sazanov A, Smith J, Burt DW, Ferguson-Smith MA, Wienberg J: Micro- and macrochromosome paints generated by flow cytometry and microdissection: tools for mapping the chicken genome. Cytogenet Cell Genet 87:278-281 (1999).

Yang F, O’Brien PCM, Milne BS, Graphodatsky AS, Solanky N, Trifonov V, Rens W, Sargan D, Ferguson-Smith MA: A complete comparative chromosome map for the dog, red fox and human and its integration with canine genetic maps. Genomics 62:189-202 (1999).

Phillips N, Bridgeman J, Ferguson-Smith MA: Report of the Inquiry into the emergence and identification of BSE and vCJD. The Stationery Office No.887 (http://www.bseinquiry.gov.uk) (2000).

Yang F, Graphodatsky AS, O'Brien PCM, Colabella A, Solanky N, Squire M, Sargan DR, Ferguson-Smith MA: Reciprocal chromosome painting illuminates the history of genome evolution of the domestic cat, dog and human. Chromosome Res 8:393-404 (2000).

Harrison CJ, Yang F, Butler T, Cheung KL, O'Brien PCM, Hennessy BJ, Prentice HG, Ferguson-Smith MA: Cross-species colour banding in the cases of myeloid malignancies with complex karyotypes. Genes Chromosomes Cancer 30:15-24 (2001).

Rens W, O’Brien PCM, Yang F, Solanky N, Perelman P, Graphodatsky AS, Ferguson MWJ, Svartman M, de Leo AA, Graves JAM, Ferguson-Smith MA: Karyotype relationships between distantly related marsupials from South America and Australia. Chromosome Res 9:301-308 (2001).

Graphodatsky AS, Yang F, Perelman PL, O’Brien PCM, Serdukova NA, Milne BS, Biltueva LS, Fu B, Vorobieva NV, Kawada SI, Robinson TJ, FergusonSmith MA: Comparative molecular cytogenetic studies in the order Carnivora: mapping chromosomal rearrangements onto the phylogenetic tree. Cytogenet Genome Res 96:137-145 (2002).

Kasai F, Garcia C, Arruga MV, Ferguson-Smith MA: Chromosome homology between chicken (Gallus gallus domesticus) and the red-legged partridge (Alectoris rufa): evidence of the occurrence of a neocentromere during evolution. Cytogenet Genome Res 102:326-330 (2003).

-Yang F, Alkalaeva EZ, Perelman PL, Pardini AT, Harrison WR, O'Brien PCM, Fu B, Graphodatsky AS, Ferguson-Smith MA, Robinson TJ: Reciprocal chromosome painting among human, aardvark, and elephant (superorder Afrotheria) reveals the likely eutherian ancestral karyotype. Proc Natl Acad Sci USA 100:1062-1066 (2003).

Yang F, Fu B, O’Brien PCM, Nie W, Ryder OA, Ferguson-Smith MA: Refined genome-wide comparative map of the domestic horse, donkey and human based on cross-species chromosome painting: insight into the occasional fertility of mules. Chromosome Res 12:65-76 (2004).

Rens W, Grützner F, O’Brien PCM, Fairclough H, Graves JAM, FergusonSmith MA: Resolution and evolution of the duck-billed platypus karyotype with a $\mathrm{X}_{1} \mathrm{Y}_{1} \mathrm{X}_{2} \mathrm{Y}_{2} \mathrm{X}_{3} \mathrm{Y}_{3} \mathrm{X}_{4} \mathrm{Y}_{4} \mathrm{X}_{5} \mathrm{Y}_{5}$ male sex chromosome constitution. Proc Natl Acad Sci USA 101:16257-16261 (2004). 